\title{
THE
}

7-7-2015

\section{Empowering Girls with Chemistry, Exercise and Physical Activity}

Emily Clapham

University of Rhode Island, eclapham@uri.edu

Lori E. Ciccomascolo

University of Rhode Island, loricicco@mail.uri.edu

Andrew J. Clapham

University of Rhode Island, aclapham@chm.uri.edu

Follow this and additional works at: https://digitalcommons.uri.edu/kinesiology_facpubs

The University of Rhode Island Faculty have made this article openly available.

Please let us know how Open Access to this research benefits you.

This is a pre-publication author manuscript of the final, published article.

Terms of Use

This article is made available under the terms and conditions applicable towards Open Access

Policy Articles, as set forth in our Terms of Use.

\section{Citation/Publisher Attribution}

Emily D. Clapham, Lori E. Ciccomascolo \& Andrew J. Clapham (2015) Empowering Girls with Chemistry, Exercise and Physical Activity, Strategies, 28:4, 40-46, DOI: 10.1080/08924562.2015.1044143

Available at: http://dx.doi.org/10.1080/08924562.2015.1044143

This Article is brought to you for free and open access by the Kinesiology at DigitalCommons@URI. It has been accepted for inclusion in Kinesiology Faculty Publications by an authorized administrator of DigitalCommons@URI. For more information, please contact digitalcommons-group@uri.edu. 
Emily D. Clapham, Ed.D.

eclapham@uri.edu

University of Rhode Island

10

Lori E. Ciccomascolo, Ed.D. aclapham@chm.uri.edu 
CHEMISTRY, EXERCISE AND PHYSICAL ACTIVITY

\section{Abstract}

32 engineering and mathematics (STEM) declines between grades 6 and 8. Similarly, in

33 middle school, there is a decrease in physical activity among girls. Researchers at the

34 University of Rhode Island (URI) conducted a chemistry-based science camp that took

35 place over the public school spring break with the goal of increasing girls' interest in

36 chemistry and physical activity. The camp included 42 middle school aged girls in grades

376 through 8 from schools throughout Rhode Island. Interdisciplinary curricula were

38 created to link chemistry with physical activity concepts used in physical education

39 classes. Overall, the girls enjoyed the interdisciplinary curriculum and found the

40 connection between science and physical activity to be interesting; as a result, similar

41 science-based interdisciplinary curricula may have the capacity to promote physical

42 activity as well as STEM career interests in girls.

43 Key words: Curriculum \& Instruction, Kinesiology, Middle School Physical Education, 44 and Teaching 


\section{CHEMISTRY, EXERCISE AND PHYSICAL ACTIVITY}

\section{Introduction}

46 Girls lose interest in both science and physical activity when they reach the

47 middle school level (Girl Scouts of America, 2013; CDC, 2013). This loss of interest in

48 areas such as science, technology, engineering and mathematics (STEM) and physical

49 activity impacts girls as they enter important life phases (e.g. high school, college, and

50 future careers), and lifestyle choices associated with these phases (Girl Scouts of

51 America, 2013). Middle school students are extremely vulnerable to behaviors that place

52 them "at risk" physically, socially, emotionally, and academically due to the many

53 changes occurring in their lives and the increase in decision-making opportunities.

54 (Mohnsen, 1997; Staurowsky, E.J. et. al, 2009).

55 Chemistry/STEM Background

56 According to data from the National Science Foundation (NSF) only 25 percent of

57 computing/math positions and 11 percent of engineering positions were held by women

58 (NSF, 2014). In contrast, women make up 47 percent of the employed workforce (NSF,

59 2014). The NSF estimates that approximately five million individuals work directly in

60 science, engineering, and technology, just over 4 percent of the work force (2014). Many

61 science and engineering occupations are predicted to grow faster than the average rate for

62 all occupations, and some of the largest increases will be in computer-related fields;

63 fields where women currently hold one-quarter or fewer positions (AAUW, 2013).

64 Attracting and retaining more women in the STEM workforce will maximize innovation,

65 creativity, and competitiveness (e.g., homes designed by women with women's needs in

66 mind). With a more diverse workforce, scientific and technological products, services,

67 and solutions are likely to be better designed. 


\section{CHEMISTRY, EXERCISE AND PHYSICAL ACTIVITY}

A lack of interest in STEM may be a product of older stereotypes about girls

69 doing poorly in math, of low confidence in their abilities, or girls turning to their high

70 verbal skills during career planning (Girl Scouts of America, 2013; Mason, 2010;

71 National Engineers Week Foundation, 2010). Research demonstrates how negative

72 stereotypes about women's math abilities are transmitted to girls by their parents and

73 teachers as early as preschool and elementary school, shaping girls' math attitudes and

74 ultimately undermining performance and interest in STEM (Gunderson, Ramirez, Levine

75 \& Beilock, 2011; NSF, 2006). Research also points to the notion of "a sense of

76 belonging" as an important factor in women's intentions to continue in the field of math.

77 An environment that communicates the idea of math ability being a field trait and not

78 something that hard work can increase can erode a girl's sense of belonging (Fine, 2010).

79 Further, girls are typically more interested in careers where they can help others (e.g.,

80 teaching, child care, working with animals) and make the world a better place (Girl

81 Scouts of America, 2013). Additionally, gender barriers often hinder girls from their

82 interest in STEM. More than half $(57 \%)$ of all young girls say that peers their age don't

83 typically consider a career in STEM. Nearly half (47\%) of all girls say that they would

84 feel uncomfortable being the only girl in a group or class. Furthermore, 57\% of all girls

85 say that if they went into a STEM career, they'd have to work harder than a man just to

86 be taken seriously (Girl Scouts of America, 2013, NSF, 2006). Finally, fewer girls than

87 boys take advanced placement (AP) exams in STEM-related subjects such as calculus,

88 physics, computer science, and chemistry, and girls who take STEM AP exams earn

89 lower scores than boys on average (AAUW, 2013).

90 Physical Activity Background 


\section{CHEMISTRY, EXERCISE AND PHYSICAL ACTIVITY}

91 Regular physical activity in childhood and adolescence improves: strength and

92 endurance, helps build healthy bones and muscles, helps control weight, reduces anxiety

93 and stress, increases self-esteem, and may improve blood pressure and cholesterol levels

94 (CDC, 2013). The U.S. Department of Health and Human Services recommends that

95 young people aged 6-17 years participate in at least 60 minutes of physical activity daily

96 (CDC, 2013; USDHHS, 2014).

97 Physical activity decreases in all adolescents throughout middle and high school. In

$982011,29 \%$ of high school students surveyed had participated in at least 60 minutes per

99 day of physical activity on all 7 days before the survey, and only $31 \%$ attended physical

100 education class daily (CDC, 2013). However, it should be noted that this decrease in

101 physical activity is more pronounced in adolescent girls. Over eighteen percent of

102 females and $38.3 \%$ of males had at least 60 minutes/day of physical activity. In addition,

$10327.2 \%$ of females and $34.6 \%$ of males attended physical education class daily (CDC,

104 2013). Furthermore, only 35\% of females aged 6-11 years are reaching the goals of 60

105 minutes of physical activity a day, and this decreases to $3 \%$ in 12 - to 15 -year-olds

106 (Troiano, Berrigan, Dodd, Masses, Tilert, McDowell, 2008). As students get older their

107 physical activity decreases, a disturbing trend seen more so in girls compared to boys

108 (CDC, 2013; Troiano et al., 2008; YRBS, 2011).

109 Connecting Chemistry to Physical Activity:

110 A significant amount of research has indicated a positive relationship between

111 academic achievement and physical activity and fitness in school-aged children (Buck,

112 Hillman, \& Castelli, 2008; Castelli, Hillman, Buck, \& Erwin, 2007; Coe, Pivarnik,

113 Womack, Reeves, \& Malina, 2006; Welk et al. 2010; Wittberg, Cottrell, Davis, \& 


\section{CHEMISTRY, EXERCISE AND PHYSICAL ACTIVITY}

114 Northrup, 2010). Scholars have suggested that improvements in academic achievement as

115 a result of increased physical activity may be due to increased arousal and reduced

116 boredom, which may result in increased attention span and concentration (Coe et al.,

117 2006) and increased self-esteem which may lead to improvements in on-task classroom

118 behavior (Shepard, 1996). There are also physiological responses to regular physical

119 activity including "increased cerebral blood flow, changes in hormone levels, greater

120 arousal and stimulation, alterations in brain neurotransmitter activity, and improved

121 nutrient intake" (Eveland-Sayers, Farely, Fuller, Morgan, \& Caputo, 2009, p. 103), all of

122 which have been associated with enhanced academic performance.

123 Due to increased emphasis on academics and testing requirements in schools, PE

124 teachers are encouraged to incorporate interdisciplinary activities into their daily lessons.

125 The use of interdisciplinary lesson plans that connect chemistry and physical activity

126 concepts in physical education classes might help girls maintain an interest in science and

127 physical activity by incorporating science concepts into fun physical activities. This

128 concept is directly connected to the New PE philosophy. According to Sullivan \&

129 Clapham (2009 \& 2014) the New PE has the following characteristics:

130 - Class is called Physical Education as we educate the physical

$131 \quad$ - (and more than the physical too)

132

133

- Everyone active, all inclusive, small groups

134

- No humiliation and intimidation

135

136

137

- Cooperative focus with enjoyment

138

139

140

141

142

143

- Fitness is blended with other physical education content

- Motivational devices are used to personalize and monitor physical activity

- Enjoyment levels are raised

- Individuals work at own physical level and challenge themselves by setting personal goals

- Wellness or health related focus

- Each child has their own piece of equipment (most of time or all active in some way)

- Each child is working towards their own personal fitness goals throughout the 
CHEMISTRY, EXERCISE AND PHYSICAL ACTIVITY

144

145

146

147

148

149

150 disciplines. Experts in promoting girls' awareness and interest in STEM suggest offering

151 programs that are engaging, have a "wow" factor, convey key concepts and applications,

152 are doable with minimal or inexpensive materials and work well in a one-hour time frame

153 (Lawrence \& Mancuso, 2012).

154 Description of the Camp/Methods

155 A week long camp took place Monday through Friday over a public school vacation

156 for 42 Rhode Island middle school girls in grades 6-8. The URI Chemistry Department

157 recruited the girls for the camp though an email sent to middle school science teachers.

158 The purpose of the camp was to use and introduce innovative curriculum in science and

159 physical education. It was the investigators' goal to create curricula that could be

160 replicated and utilized by middle school physical education teachers in daily physical

161 education classes. Interdisciplinary chemistry and physical activity lessons were taught to

162 the camp participants to foster interest and appreciation of science and physical

163 education.

164 The camp, sponsored by the URI Chemistry Department, took place each day from

165 8:30am to 4:30pm. Chemistry professors, graduate students and guest speakers presented

166 chemistry topics and experiments from the field. The topics throughout the camp

167 included: Nano-science, non-Newtonian Fluids, Ph of common objects, rainbow

168 chemistry, women in science, polymer chemistry, and magic show experiments. There 


\section{CHEMISTRY, EXERCISE AND PHYSICAL ACTIVITY}

169 were also field trips to the Narragansett Bay Commission and Boston Museum of

170 Science.

171 The URI Department of Kinesiology sponsored 60 minutes of physical activity (PA)

172 each day of the camp. This took place from $12 \mathrm{pm}$ to $1 \mathrm{pm}$ each day. During the 60

173 minutes of PA each day, a 1-week (4 lesson) interdisciplinary unit was developed to

174 reinforce and complement the chemistry topics that were covered during the camp and to

175 introduce new health and physical activity topics. Music with empowering, pro-female

176 messages was played during the lessons and included "Girl is On Fire" by Alicia Keys,

177 "Miss Independent” by Kelly Clarkson, "Born this Way" by Lady Gaga, "Firework" by

178 Katy Perry, "Run the World (girls) by Beyonce' and "Beautiful” by Christina Aguilera.

179 The girls were also given a white Polar Active activity monitor to wear throughout

180 the camp to monitor the amount and type of physical activity. Each Polar Active was

181 individually programmed with each girl's height, weight, birth date and gender. The

182 instructor explained how to use the Polar Actives (i.e., wear them like a watch on your

183 wrist) and that they measured amount of physical activity in steps, level of physical

184 activity by category (easy, moderate, moderate-vigorous, vigorous and vigorous + ) and

185 calories expended. The importance of monitoring physical activity was also thoroughly

186 explained to the camp participants (e.g. to be aware of physical activity level and amount

187 to live a healthy lifestyle). Please see figure 1 for a picture of a Polar Active.

188 Description of the Chemistry and Physical Education Lessons and Activities:

189 Lesson 1: Introduction: What is an activity monitor or Polar Active? How do I use a Polar

190 Active? What will I be doing with the Polar Active? 


\section{CHEMISTRY, EXERCISE AND PHYSICAL ACTIVITY}

191 Warm-up Description: Blob tag: Cone off a large space and let players know to stay

192 between the cones at all times. Begin the game with two girls ("the blob") holding hands.

193 If "the blob" tags a player, the girls will join "the blob" by holding their hands. Once "the

194 blob" forms a group of 5, the girls are told that mitosis (cell division) has occurred and

195 the teams will be made into two smaller groups of 2 and 3. The girls will understand that

196 it is a bit easier for "the blob" to move around. Once the blob tags everyone, the game

197 was over.

198 Interdisciplinary Chemistry and Physical Education Topics: Questions: What type of

199 chemical reactions occur in your body? What do we fuel our bodies with? (food). Do the

200 different types of food we choose to eat (fuel) causes chemical reactions in our bodies?

201 Why is it important to fuel our bodies with good food?

202 Action: The instructor will lead a discussion on various chemical reactions that occur in

203 the body on a regular basis (i.e.. saliva breaks down food, sweat cools your body and

204 carbohydrates provide your body with energy). The instructor will also discuss food as

205 fuel for the body and the importance of eating healthy food with Choosemyplate.gov.

206 Interdisciplinary Physical Activity: Healthy Plate Scramble: Create Teams of 3-4 girls

207 and give each team a hula-hoop (plate). Each team will set up their plate in a circle

208 around bean-bags (food groups). The girls will be told to create a healthy plate of food

209 with fruits, vegetables, grains, protein and dairy. The bean bags will be coded by color:

210 red will represent protein, blue will represent dairy, green will represent vegetables,

211 yellow will represent grains, and purple will represent fruit. The girls will attempt to grab

212 one beanbag out of the middle of the floor at a time. Only one girl from each team will be

213 asked to choose a bean-bag when they are told. Once all of the beanbags are gone from 


\section{CHEMISTRY, EXERCISE AND PHYSICAL ACTIVITY}

214 the middle of the floor, the girls will need to take the appropriate color they need from the

215 other teams (similar to Capture the Flag). The girls will not be able to guard their

216 beanbags (food groups) in their hoop (plate).

217 Closure: Handouts will be given to the girls from choosemyplate.gov.

218 Lesson 2: Introduction: What is the $\mathrm{pH}$ of your body fluids? (Blood has a $\mathrm{pH}$ of 7.4,

219 sweat has a $\mathrm{pH}$ of 4 and tears have a $\mathrm{pH}$ of 6.5).

220 Warm-up Description: Blood, Sweat and Tears Tag: The instructor will split the girls into

221 two teams. Each team will be sent to opposite sides of the gym or space provided. Each

222 team will need to choose one body fluid to represent (i.e., blood, sweat or tears like

223 "rock, paper, scissors"). For the purpose of the activity, blood beats tears because it has a

224 higher $\mathrm{pH}$, tears beat sweat because it has a higher $\mathrm{pH}$ and sweat beats blood because it

225 can wash away blood. The teams will start on opposite baselines and walk to the center of

226 the gym in a line formation together. They can chant as they walk "blood, sweat, tears,

227 repeat". Once they get into the middle, like "rocks, paper, scissors", they say "blood,

228 sweat, tears" then the body fluid they chose as a team. The winning team will try to tag

229 the losing team, while the losing team retreats to their baseline. Anyone who is tagged

230 will need to join the winning team. The purpose of the activity is to learn the differences

231 in $\mathrm{pH}$ between the three body fluids.

232 Interdisciplinary Chemistry and Physical Education Topic: Questions: What is the

233 connection between care and treatment for athletic injuries with stretching and

234 nanoscience? What is nanoscience? (The study of small things and can be connected to

235 physical activity by using small movements and muscle contractions). 


\section{CHEMISTRY, EXERCISE AND PHYSICAL ACTIVITY}

236 Interdisciplinary Physical Activity: Yoga poses will be introduced to the girls. The

237 instructor will explain that yoga can be empowering, prevent athletic injuries, and relate

238 to nanoscience by using small movements to substantially improve muscular strength by

239 toning small muscles. Common yoga poses such as the Tree pose, Child pose, Bridge

240 pose, Cobra pose, Plank pose, Downward dog, Warrior pose, and Sun salutation will be

241 introduced. Please see the appendix for a description of each of the poses.

242 Closure: The girls will be given handouts on the yoga poses.

243 Lesson 3: Introduction: The girls will learn about the chemistry of marine environments,

244 water and salts. Why does saline play an important role in one's body functions? What

245 are electrolytes? (Electrolytes help nutrients move into the body's cells and help wastes

246 move out. They also aid in the stabilization of the body's $\mathrm{pH}$ level. Electrolytes can affect

247 your heart rhythm, your muscles' ability to contract, your brain function and energy

248 level). Why is hydration so important? It is important to drink a lot of water, and other

249 low-sugar sports drinks or snacks to replace the electrolytes that one loses during

250 strenuous exercise). What are some things that are made up of saline?

251 Warm-up Description: Saline Sprint tag game: The instructor will randomly select

252 several taggers. The taggers will be given a rubber chicken to use. When tagged with the

253 rubber chicken the girls will be asked to name something (e.g. ocean water, tears, sweat,

254 saline spray) with a saline make-up and then tell a friend in order to get back into the

255 game. The taggers will be switched up every couple of minutes.

256 Interdisciplinary Chemistry and Physical Education Topic:

257 Questions: How does one prevent injuries, especially knees? (Jumping and landing

258 lightly and changing posture). What are polymers? 


\section{CHEMISTRY, EXERCISE AND PHYSICAL ACTIVITY}

259 Action: The girls will be told to use a quarter squat with a natural bend in the knee, chin

260 up, chest out, and buttocks back. They girls will be shown how polymers in athletic shoes

261 can assist in preventing injuries by providing cushioning to aid in absorbing shock.

262 Closure: Name a polymer! The girls will be asked to name things that are physical

263 activity related that have polymers. Some examples can include rubber PE equipment

264 balls, plastic jump ropes, hula-hoops, and other PE clothing like sports bras, athletic

265 shoes, and dry fit clothing.

266 Interdisciplinary Physical Activity: The girls will participate in jumping using proper

267 form on several different surfaces e.g. turf, gym floor, and grass. Several jumping

268 stations, including ladders, will be set up to create various movement patterns, jumping

269 with jump ropes, high jumps, and plyometric jumping activities. The girls will rotate

270 through the jumping stations.

271 Lesson 4: The girls will go on a field trip that is interdisciplinary (chemistry and physical

272 activity) in nature. The girls in this camp visited the Boston Museum of Science and wore

273 their Polar Actives on the trip.

274 Lesson 5: Introduction: What are some benefits of physical activity? Isn't physical

275 activity fun? How much PA did you get this week? What Type of PA?

276 Warm-up Description: Instructors will review all science topics covered all week with

277 fitness relay races with science vocabulary words (polymer, saline, explosive movements,

278 perceived exertion, nanoscience, mitosis, Non-Newtonian Fluids, pH of blood, sweat and

279 tears). The girls will be split up into 10 groups of 4-5. Each girl will dribble a basketball

280 in between the cones to the opposite side of the gym and then take a shot find a

281 vocabulary word and the correct definition and then dribble back. Once the girl has 


\section{CHEMISTRY, EXERCISE AND PHYSICAL ACTIVITY}

282 successfully dribbled back and passed the basketball to the next girl in line, she can take a

283 seat and her teammate will complete the same challenge. The girls were encouraged to

284 cheer for their teammates!

285 Interdisciplinary Chemistry and Physical Education Topic: What is the scale of perceived

286 exertion and how does it relate to physical activity (using the Polar Actives).

287 Action: The girls will do explosive movements, experiencing Non-Newtonian Fluids, by

288 walking through "kiddie" pools of cornstarch and water. The girls will learn that viscosity

289 depends on the force applied to the liquid or how fast an object is moving through the

290 liquid.

291 Interdisciplinary Physical Activity: The girls will participate in a Fitness Obstacle Course

292 with explosive movements and "kiddie" pools with cornstarch and water (forms a

293 quicksand substance). A fitness obstacle course will be set up outside with hoops that the

294 girls will jump through, cones to zigzag and sprint through, high jumps using correct

295 form, jump bands to jump over, and "kiddie pools" of corn starch and water to run

296 through to finish.

297 Closure: The girls will be given a Scale of Perceived Exertion handout. The girls will be

298 asked about their perceived exertion for each physical activity they completed. The girls

299 will be given printouts of their daily and weekly physical activity data from the Polar

300 Actives. The instructor will discuss and review the amount and type of their physical

301 activity and discuss setting future physical activity personal goals. The girls will be asked

302 which activities they liked the best and why. Please see table 1 for a display of the lessons

303 and activities.

304 Conclusion 


\section{CHEMISTRY, EXERCISE AND PHYSICAL ACTIVITY}

Overall, the girls enjoyed all of the activities and found science and physical

306 activity fun and interesting. It is critical to instill a love of science and physical activity in

307 middle school girls, since they often lose interest in these two areas during this time in

308 life. The loss of interest in science and physical activity is significant because it impacts

309 girls' lifestyle and career choices as they enter in high school and transition into college.

310 As such, a middle school physical education class is an ideal environment to present fun

311 and engaging science- based interdisciplinary lessons like the curricula presented, to

312 improve a girl's health and well-being and to enhance potential connections between

313 physical activity and academic achievements in STEM. Connecting physical activity and

314 sport to STEM activities for girls is also a matter of gender equity. Since 1972, Title IX

315 has provided an equal opportunity for girls and women to participate in sport and

316 physical activity. But just as Title IX has provided an equal opportunity for girls with an

317 interest in sport and physical activity to pursue that interest, the law continues to mandate

318 greater educational opportunities, funded by federal agencies, for both girls and boys,

319 including STEM education (NCGWE, 2012). Similar to physical activity and sport, Title

320 IX has provided more of an opportunity for girls to explore different educational

321 possibilities that were typically more male-dominated, like STEM, and has positively

322 affected girls' achievement in math scores on the SATs over the last two decades

323 (NCGWE, 2012). Chemistry and physical activity can be connected in interdisciplinary

324 physical education lessons to help stimulate girls' interest in science and physical

325 activity. Interdisciplinary curricula like these could also aid in increasing and sustaining

326 the interest of girls in STEM fields and participation in a physically active lifestyle. 


\section{CHEMISTRY, EXERCISE AND PHYSICAL ACTIVITY}

\section{References:}

American Association of University Women. (2013) Chapter 1: Women and Girls in Science, Technology, Engineering, and Mathematics. Retrieved on June 1, 2013 from: http://www.nature.com/scitable/content/chapter-1-women-and-girls-in-science-18040707

Buck, S.M., Hillman, C.H., \& Castelli, D.M. (2008). The relation of aerobic fitness to stroop task performance in preadolescent children. Medicine and Science in Sports and Exercise, 40(1), 166-172.

Castelli. D.M., Hillman, C.H., Buck, S. M., \& Erwin, H.E. (2007). Physical fitness and academic achievement in third- and fifth-grade students. Journal of Sport and Exercise Psychology, 29, 239-252).

Centers For Disease Control and Prevention (2013). How much physical activity do children need? Retrieved on June 1, 2013 from:

http://www.cdc.gov/physicalactivity/everyone/guidelines/children.html

Centers For Disease Control and Prevention (2013). Youth Risk Behavior SurveillanceUnited States 2011. Retrieved on October 9, 2013 from

http://www.cdc.gov/mmwr/pdf/ss/ss6104.pdf

Clapham, E.D \& Sullivan, E.C. (2014). Tacking and Jibing: Finding Wind for Technology and the New PE. PowerPoint Presentation at Eastern District AAHPERD Convention (February, 2014). Newport, RI: EDA AAHPERD.

Coe, D.P., Pivarnick, J.M., Womack, C.J., Reeves, M.J., \& Malina, R.M. (2006). Effect of physical education and activity levels on academic achievement in children. Medicine and Exercise Science in Sport and Exercise, 38(8), 1515-1519.

Eveland-Sayers. B.M., Farely, R.S., Fuller, D.K., Morgan, D.W., \& Caputo, J.L. (2009). Physical fitness and academic achievement in elementary school children. Journal of Physical Activity and Health, 6, 99-104.

Fine, C. (2010). Delusions of Gender: How Our Minds, Society, and Neurosexism Create Differences. NYC, NY: W.W. Norton \& Company.

Gunderson, E.A., Ramirez, G., Levine, S.C., \& Beilock, S.L. (2011). The role of parents and teachers in the development of gender-related math attitudes. Sex Roles, 66, 153-166.

Lawrence, D.A. \& Mancuso, T.A. (2010). Promoting Girls' Awareness and Interest in Engineering. Technology and Education Teacher, September 2012, 11-16.

Mason, M.A. (2010). Still earning less. Chronicle of Higher Education. Retrieved on August, 7, 2014 from http://chronicle.com/article/Stll-Earning-Less/63482/. 


\section{CHEMISTRY, EXERCISE AND PHYSICAL ACTIVITY}

Mohnsen, B.S. (1997). Teaching middle school physical education. Champaign, IL: Human Kinetics.

Staurowsky, E.J., DeSousa, M.J., Ducher, G., Gentner, N., \& Williams, N. (2009). Her Life Depends On It II: Sport, Physical Activity, and the Health and Well-Being of American Girls and Women. East Meadow, NY: Women's Sports Foundation.

National Coalition for Women and Girls in Education (NCWGE). Title IX at 40: Working to Ensure Gender Equity in Education. Washington, DC: NCWGE, 2012.

National Science Foundation (2006). New tools for America's work force: girls in science and engineering (NSF 06-59). Arlington, VA: Author.

National Science Foundation, 2013. Women, Minorities, and Person's with Disabilities in Science and Engineering. Retrieved on January 28, 2014 from http://www.nsf.gov/statistics/wmpd/2013/sex.cfm.

Shephard, R.J. (1996). Habitual physical activity and academic performance, Nutrition Reviews, 54(4), S32-S36.

The Girl Scouts of America. (2013). Generation STEM: What Girls Say About Science, Technology, Engineering and Math. Retrieved on June 1, 2013 from: http://www.girlscouts.org/research/pdf/generation_stem_full_report.pdf

Troiano, R.P., Berrigan, D., Dodd, K.W., Masse, L.C., Tilert, T., McDowell, M. (2008). Physical activity in the United States measured by accelerometer. Medical Science Sports Exercise, 40(1):181-188.

United States Department of Agriculture. (2013). Printable Materials and Ordering. Retrieved on June 1, 2013 from: http://www.choosemyplate.gov/print-materialsordering/graphic-resources.html

United States Department of Health and Human Services. (2008). Physical Activity Guidelines for Americans. Office of Disease Prevention and Health Promotion. Retrieved on August 5, 2014 from: http://www.health.gov/paguidelines/guigelines/.

Welk, G.J., Jackson, A.W., Morrow, J.R., Haskell, W.H., Meredith, M.D., \& Cooper, K.H. (2010). The association of health-related fitness with indicators of academic performance in Texas schools. Research Quarterly for Exercise and Sport, 81(3), S16S23.

Wittberg, R., Cottrell, L.A., Davis, C.L., \& Northup, K.L. (2010). Aerobic fitness thresholds associated with fifth grade academic achievement. American Journal of Health Education, 41(5), 284-291. 